\title{
Life Cycle Assessment (LCA) of Wood Pellet Production at Korintiga Hutani Company, Central Kalimantan, Indonesia
}

\author{
Iswanto ${ }^{1}$, Dodik Ridho Nurrochmat ${ }^{2}$, Ulfah Juniarti Siregar ${ }^{3 *}$ \\ Graduate Program of Tropical Silviculture, Faculty of Forestry and Environment, IPB University, Academic Ring Road \\ Campus IPB Dramaga, Bogor, Indonesia 16680 \\ ${ }^{2}$ Department of Management Forestry, Faculty of Forestry and Environment, IPB University, Academic Ring Road Campus \\ IPB Dramaga, Bogor, Indonesia 16680 \\ ${ }^{3}$ Department of Silviculture, Faculty of Forestry and Environment, IPB University, Academic Ring Road Campus IPB \\ Dramaga, Bogor, Indonesia 16680
}

Received November 30, 2020/Accepted December 9, 2021

\begin{abstract}
Climate change has forced human being to adapt in fulfilling their energy needs sustainably. In Indonesia, forestry activities has been considered as an emission rather than carbon sink. This study aims to analyze the inputs, outputs, and potential environmental impacts of wood pellet production in a forest company using life cycle assessment (LCA). The wood pellet is made from Eucalyptus pellita plantation. Analysis was made for 1 planting cycle or 6 years, and allometric equations were used to estimate the ability of industrial timber plantation forest to absorb $\mathrm{CO}_{2}$. Production of wood pellet starting from plantation requires inputs as follows: diesel fuel, electricity, NPK and other fertilizers, pesticides, and electrical energy. Those inputs produced emissions, of which the largest was $\mathrm{N}_{2} \mathrm{O}$ of $551.2927 \mathrm{~kg}$, followed by $\mathrm{NH}_{3}$ of $7.5275 \mathrm{~kg}$ generated from NPK fertilizer. Another was $\mathrm{PO}_{4}^{3-}$ amounted at $0.1792-0.2229 \mathrm{~kg}$ from liquid fertilizers and pesticides. Potential acidification came from $13.3675 \mathrm{~kg} \mathrm{SO}, \mathrm{eq}$, and eutrophication of $0.4021 \mathrm{~kg} \mathrm{PO}{ }_{4}^{3-} \mathrm{eq}$. The greenhouse gas (GHG) emission was $678.0270 \mathrm{~kg} \mathrm{CO}$ eq from the plantation activities, especially from diesel-based energy consumption, while wood pellet mills only released 0.1053 $\mathrm{kg} \mathrm{CO}{ }_{2}$ eq of $\mathrm{GHG}$ emissions. Thus, total emissions from 6 years' time of wood pellet production are much lower compared to the average $\mathrm{CO}_{2}$ absorbed by the plantation forest, of which annually is 36.34-67.69 ton ha $\mathrm{a}^{-1} \mathrm{year}^{-1}$.
\end{abstract}

Keywords: acidification, eutrophication, greenhouse gases, life cycle assessment

*Correspondence author,email:ulfahjs@apps.ipb.ac.id

\section{Introduction}

Climate change has become a serious threat to human race due to its vital impact on basic human needs such as food production, water distribution, and energy. Through the Paris Climate Agreement at the COP21 UNFCCC in 2015, several countries agreed to limit the earth surface temperature increase by no more than $2 \mathrm{C}$ from pre-industrialization and strive to further decrease the global surface temperature to 1.5C (UNFCCC, 2015). Indonesia's participation in the Paris Agreement then encouraged the government to be actively involved in efforts to reduce emissions at the national level. Indonesia aims to reduce emissions through the National Determined Contribution (NDC) by $29 \%$ with the national efforts from the business as usual (BAU), and $41 \%$ by 2030 through international cooperation. The target requires a specific approach for Indonesia, given that Indonesia is one of the countries with the largest forests that presumably able to absorb the largest carbon in the world, while on the other hand, deforestation as well as land and forest conversion are still happening on a massive scale (Aisya, 2019).

Forest land status and management determine whether certain land will serve as carbon sink (net sink) or otherwise carbon emitter (source of emission). Deforestation, forest degradation, and land use change are considered as main source of emissions in Indonesia. Thus, Indonesia's stance in the Paris Agreement has posed a challenge to reduce national emissions through forest carbon absorption in the form of plantation forests.

Plantation forests possess varied environmental services such as carbon sequestration, hydrological cycle regulation, biodiversity conservation, and reducing open land (Baubus et al., 2010). In addition, meeting the demand for timber and wood fiber for industrial raw materials from forest plantation rather than natural forests becomes one of the ways to overcome climate change by controlling the deforestation rate (Carle et al., 2002). Under the Memorandum of Understanding between Indonesian Ministry of Energy and Mineral Resources (MEMR) and Indonesian Ministry of Environment and Forestry (MoEF) in 2014, both ministries urged diverse utilization of industrial timber plantation (ITP or hutan tanaman industri/HTI) as clean energy source, while power plant service providers were encouraged to invest in the clean energy sector. Hence, many concession holders have promised to revise their forest management plans by inclusion of biomass-based energy production aside from usual timber. However, the program has not yet fully implemented by all registered ITP companies. One ITP company that have started to implement the program is PT. Korintiga Hutani (PT KTH) in West Kotawaringin District, Central Kalimantan Province. This company produces not 
only timber for its timber industry, but also wood pellet from its Eucalyptus pellita plantation.

Wood pellets derived from forest biomass are more environmental friendly to substitute fossil energy (Kaygusuz et al., 2017). In the case of biomass utilization as an energy source, several factors need to be considered, i.e energy efficiency of the conversion technology, the efficiency of the life cycle and its impact on the environment; an evaluation is needed at the life cycle stage of biomass production, starting from production, processing, and energy conversion (Shinya $\&$ Yukihiko, 2008). One technique to assess the environmental impact is life cycle assessment (LCA). According to the United States Environmental Protection Agency (EPA), LCA is a method to analyse potential environmental impacts associated with a product, process, or service (http://www.epa.gov/nrmrl/std/lca/lca.html). LCA is able to identify advantages or benefits of a product for different impact categories concerning the local or global environment (Daddi et al., 2017).

The greenhouse gas (GHG) emissions and other emissions controls need to focus on efficiency in the energy production, transmission, distribution, and consumption (Kuzgunkaya, 2015). Current publications on wood pellet products mainly emphasizes on the environmental aspects of the renewable energy but rarely focused on the life cycle aspects of wood pellet products. Agostini et al. (2019) states that the common renewable energy studied is biodiesel originating from oil-producing seeds and algae, then other massively used motor fuels such as ethanol, biomethane, and bio gasoline, while study regarding wood pellets is ranked last. Therefore, it is compulsory to have a LCA of wood pellets to identify its position in reducing the emissions as bioenergy, especially during the production process within the industrial timber plantation system which could be regarded as an emission.

This research aims to 1) analyze inputs (resources) and outputs (emission) of wood pellet production flow that includes activities in a forest plantation and wood pellet mill, and 2) analyze potential environmental impacts in the form of GHG emission, acidification, and eutrophication resulted from wood pellet production flow.

\section{Methods}

Research procedure Collection of primary and secondary data was done in 2018 at PT KTH, West Kotawaringin District, Central Kalimantan Province, Indonesia, which grows $E$. pellita. The primary data on production process was obtained from inventory and direct interviews with respondents who were responsible or involved in seedling preparation, land preparation, planting, plantation maintenance, harvesting, and production process in the mill, as well as direct field observations. The secondary data was obtained from the company's documents, including data of raw material use, specification of machines and equipment involved in each stage of the production process, as well as reports from several previous studies. This LCA method was carried out based on principles and framework of the LCA of ISO 14040:2006 as shown in Figure 1.

Defining research objectives and scopes is necessary to assure the boundary of the system in the LCA and thus gives objective results. Figure 2 shows the scope of this research, which was 'cradle to gate', meaning the entire process from generating raw material in the plantation up to wood pellet production in 1 (one) plantation cycle, i.e. 6 years' time. LCA data collection and analysis was conducted by identifying and listing all relevant inputs and outputs of the assessed system, which was done quantitatively by inventory of all processes in the plantation and wood pellet industry using Microsoft Excel. The input data comprised of materials and energy required in the life cycle, such as electricity, diesel, gasoline, fertilizers, and others. While the outputs are those which have impact on the environment, including GHG emissions, acidification, and eutrophication.

Overall analysis of the potential impact of wood pellet production was conducted by summing up all outputs, of which value was then compared to the amount of carbon sequestered by the plantation. The comparison between the amount of carbon emissions released to the atmosphere during the whole production process and those that were absorbed by the forest stands biomass would justify whether the wood pellet production is net emitter or not.

An interpretation was carried out as the final stage of the LCA procedure in the form of summary and then discussed to formulate conclusion, recommendations, as well as prime decisions according to the defined objectives and scopes of this research.

Data analysis It is well established that any agricultural input such as fertilizers and pesticides will give emissions. The standard formulas used in the calculation of GHG emissions, acidification, and eutrophication from each input are presented in Table 1 including their source of references. Calculation of the potential absorption of $\mathrm{CO}_{2}$ from $E$. pellita plantation at 6 years old, was done by calculating the tree biomass using the allometric equation $Y=2,040 \mathrm{~V}^{0.997}$ (Hardiansyah, 2012) where $\mathrm{V}$ is tree volume. The equation was derived from a measurement of $1,2,4$, and 5 years old $E$. pellita stands in the field. Allometric equation is very useful in estimating tree biomass, and thus the amount of carbon sequestered by plantation without destruction of the sample trees. The selection of allometric equation used in this study was based on the similarity of the species studied and location with similar growing conditions of the plantation. Emission factor (FE) values used in this study refer to Tier 1 (IPCC, 2006).

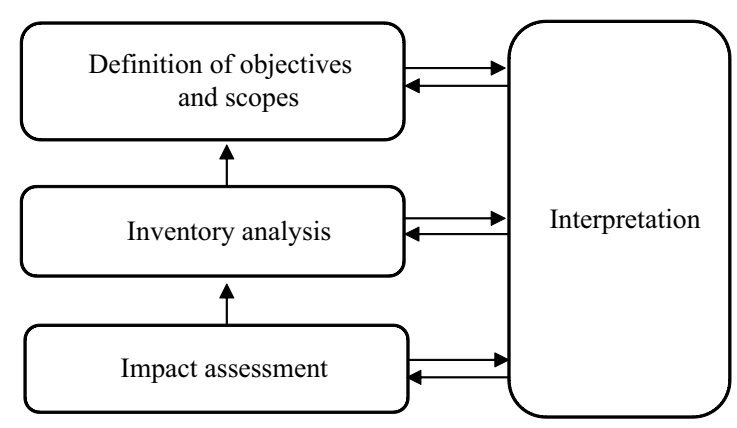

Figure 1 LCA research stages. 


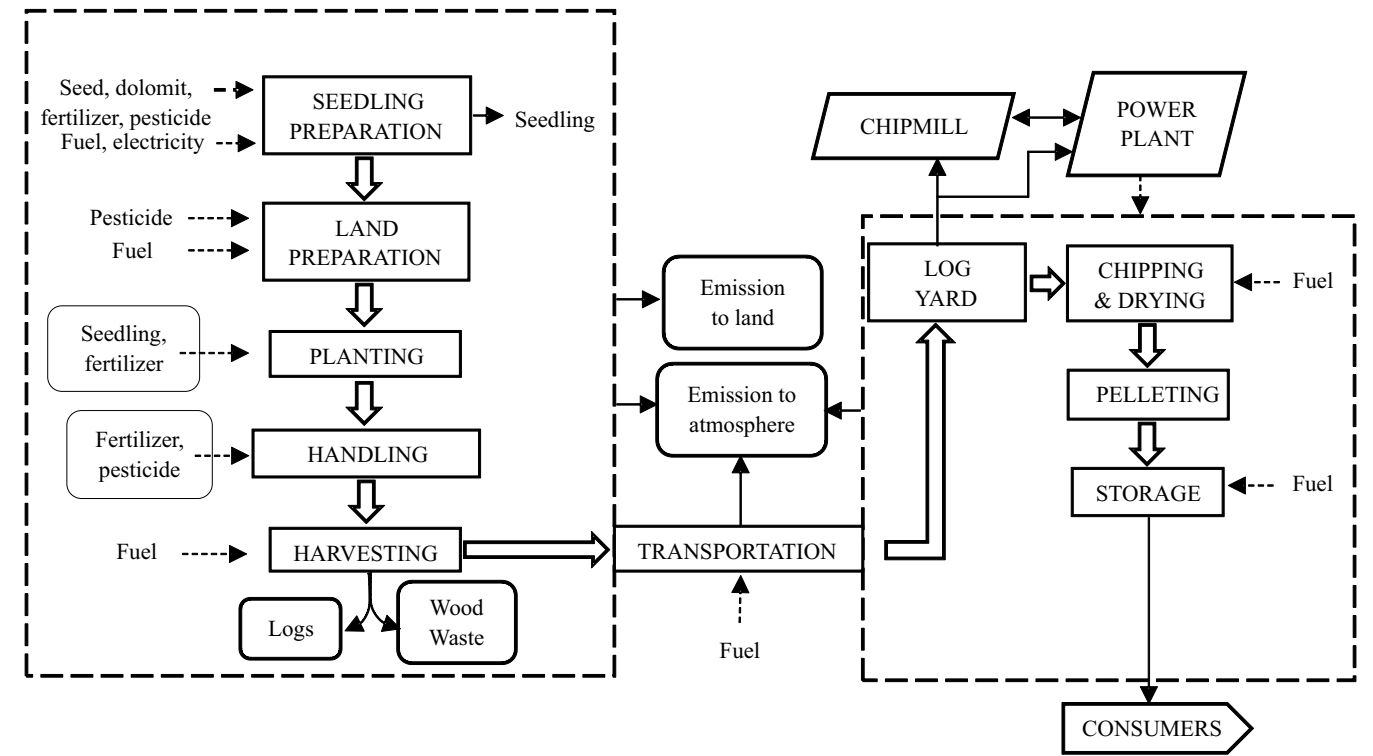

Figure 2 System boundary of wood pellet production.

Table 1 The calculation of greenhouse gases emissions, acidification, and eutrophication

\begin{tabular}{ll}
\hline \multicolumn{1}{c}{ Formulas } & \multicolumn{1}{c}{ Source } \\
\hline Emissions (Electricity) $=\mathrm{QL} \times \mathrm{FE}$ & UNFCCC (2006) \\
Emissions (Fuel) $=\mathrm{QF} \times \mathrm{NK} \times \mathrm{FE}$ & $\operatorname{IPCC~}(2006)$ \\
Emissions (Fertilizer) $=\mathrm{Qp} \times \mathrm{N} \times \mathrm{FE}$ & $\mathrm{EEA}(2006)$ \\
Emissions (Pesticides) $=\mathrm{Qps} \times \mathrm{FE}$ & $\mathrm{IPCC}(2006)$ \\
\hline
\end{tabular}

Note: $\mathrm{QL}=$ electricity consumption; $\mathrm{QF}=$ fuel consumption; $\mathrm{QP}=$ fertilizer consumption; $\mathrm{QPS}=$ pesticide consumption; $\mathrm{NK}=$ heating value; $\mathrm{FE}=$ emission factor; $\mathrm{N}=$ nitrogen

\section{Results and Discussion}

General conditions The forest concession license (IUPHHK) of PT KTH was obtained by Decree of Ministry of Forestry Number SK.219/Kpts-II/1998 in February 1998 and final addendum to the decree Number 201/MenhutII/2011nApril 2011 granting an area of 94,384 ha in West Kotawaringin District of Central Kalimantan, Indonesia. The company grows E. pellita and Table 2 shows measurement results of growth and $\mathrm{CO}_{2}$ absorption potential of $E$. pellita at $1,2,3$, and 4 years old.

According to Table 2, the volume of E. pellita at 1, 2, 3, and 4 years old increased each year. A similar tendency applies to the calculation outcome of $\mathrm{CO}_{2}$ absorption potential that ranges from 36.34-270.77 ton $\mathrm{ha}^{-1}$ or from 36.34-67.69 ton ha ${ }^{-1}$ year ${ }^{-1}$ for an annual capability to absorb $\mathrm{CO}_{2}$ on the average. According to Singh \& Toky (1995), a 4year-old Eucalyptus can produce 52.38 ton ha ${ }^{-1}$ of biomass in total. E. pellita is widely cultivated for pulp production in Indonesia because of its fast-growing properties, excellent environmental adaptability, straightness, branchless stem, easily cultivated, and high resistance to pests and diseases (Lukmandaru et al., 2016). E. pellita also yields a high and stable stem volume increment every year (Herawan \&
Leksono, 2018). According to McKendry (2002), general characteristics of an ideal energy crops are fast growth, low nutrient requirements, resistance to pest and drought, and capability to grow in local soil conditions. Timber produced by PT KTH is used to supply its relevant industrial factories, e.g., chip mill, pellet mill, etc. Refer Figure 2 for system boundary of wood pellet research.

Figure 3 illustrates wood pellet production in PT KTH, which including two stages, i.e., cultivation activity in ITP and production process in the wood pellet mill. The activity in ITP begins with seedling preparation by establishing a permanent nursery and producing seedlings from hedge orchard. Seedling maintenance was conducted using sprinkle system, manual fertilization, and pesticide spraying. The next activity is land preparation using an excavator bucket to prepare planting rows and a drill to make planting holes, as well as herbicide spraying to eradicate weeds. Once the land is ready, planting activities is conducted. The fertilizer used in transplanting was basic fertilizer, usually compost and $\mathrm{P}$ fertilizer, that was applied to each plant. During the period from planting to harvesting, maintenance that comprises fertilizing, replanting, weeding, and tilling, is conducted. The final activity in ITP is the harvesting the wood of a 6-year-old plantation. Wood waste as main material for pellet is then transported from plantation to the mill, approximately $\pm 90 \mathrm{~km}$ away. Investigation of activities in the wood chip mill was started from the final shelter (log yard) that serves as raw material storage, followed by chipping the material into smaller pieces and crushing the chips. The next process is drying to reduce the moisture content of the material followed by pelleting. In this process, the material is compressed at a certain temperature and tapioca flour is added to serve as an adhesive for the pellet. The prepared wood pellet products are then packed in a jumbo bag and placed in the storage to be then distributed to the customers. 
Table 2 Growth and absorption potential carbon dioxide of species of Eucalyptus pellita

\begin{tabular}{cccccc}
\hline $\begin{array}{c}\text { Age } \\
(\text { year })\end{array}$ & $\begin{array}{c}\text { Diameter } \\
(\mathrm{cm})\end{array}$ & $\begin{array}{c}\text { Height } \\
(\mathrm{m})\end{array}$ & $\begin{array}{c}\text { Volume } \\
\left(\mathrm{m}^{3} \mathrm{ha}^{-1}\right)\end{array}$ & $\begin{array}{c}\mathrm{CO}_{2} \text { absorption } \\
\text { potential } \\
\left(\text { ton ha }{ }^{-1}\right)\end{array}$ & $\begin{array}{c}\mathrm{CO}_{2} \text { absorption } \\
\text { per year } \\
\left(\text { ton ha } \text { year }^{-1}\right)\end{array}$ \\
\hline 1 & 6.40 & 6.50 & 20.38 & 36.34 & 36.34 \\
2 & 10.78 & 12.33 & 57.55 & 115.98 & 57.99 \\
3 & 11.58 & 16.00 & 97.35 & 195.88 & 65.29 \\
4 & 18.80 & 14.85 & 134.70 & 270.77 & 67.69 \\
\hline
\end{tabular}

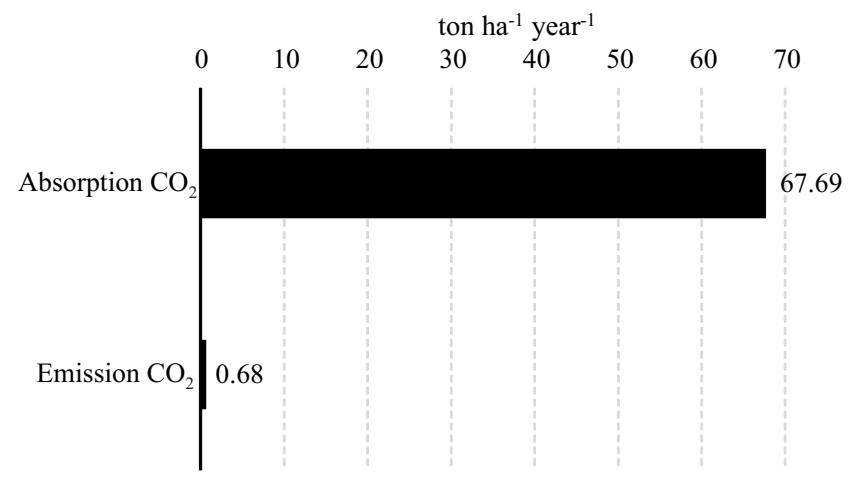

Figure $3 \mathrm{CO}_{2}$ absorption and emission.

Inventory of wood pellet production activities The inventory in the plantation and mill was carried out by calculating all the use of energy and material, based on one cycle of wood pellet production in ITP for 100 ton of wood pellets. Refer to Table 3 for energy and material input used in the plantation and wood pellet mill.

Table 3 shows the highest energy input of 1,308 kWh electricity, which is the largest electricity consumption in the whole wood pellet production process, used in the wood pellet mill. The electricity was used for chipping at the amount of $700 \mathrm{kWh}$ and pelleting process $477 \mathrm{kWh}$. Meanwhile during the plantation stage, the consumption is only $131 \mathrm{kWh}$ of electricity, which is coming from power for a water pump engine. The second largest energy input in the production system studied here is $788 \mathrm{~L}$ of diesel fuel, which is used at the plantation stage and wood pellet mill, to operate electric generator engines, rotary drills, chainsaw, bucket excavators, truck logging, and dump trucks. Table 3 also shows that the highest material input is $500 \mathrm{~kg}$ NPK fertilizer, which is required at the stage of seedlings production and plantation maintenance. The high use of diesel and fertilizer as inputs are in accordance with a study by Susanto et al. (2017), that fertilizer and energy transportation are widely used in agriculture activities. The second highest material input is P sp-36 fertilizer at amount of $111.10 \mathrm{~kg}$, required at the transplanting stage as a basic fertilizer for plants at a dose of $100 \mathrm{~g} \mathrm{plant}^{-1}$. Another input in form of ingredient is $14.86 \mathrm{~L}$ pesticides, which is used to protect plants from pests of diseases.

The result shows that the largest necessities of ITP to produce raw material of wood pellet are diesel fuel for heavy equipment, fertilizer for crop nutrients, and pesticide for crop protection from pests and diseases. The high input of fuel and fertilizer is in accordance with a statement by Aziz (2008), that most transportation equipment, agricultural equipment, heavy equipment, and generators of electricity generators use diesel fuel. The fertilizer utilization is one of the determining factors in efforts to increase plants growth and production optimally (Purba, 2014). Herbicides' spraying is required to allow the staple crops to optimally absorb the nutrients without any competition, while the quality of the product is maintained (Damalas \& Eleftherohorinos, 2011).

Activities in wood pellet mill indicate that the main source of energy in the mill is electrical energy which is supplied from the company's power plant. The raw material required to operate a boiler in the power plant is wood waste from chip mill, i.e., tree bark and decayed wood. The recycle of tree biomass generated in this system has made this system environmental friendly or carbon-neutral process compared to fossil fuel, because carbon dioxide that is released during the combustion is later absorbed by the crops (Moreno et al., 2019). Hence, the emission from the energy generation was not calculated as it does not employ fossil fuel and instead, utilizes the mill's wood waste. Wood waste is also used for the energy needed in the pulp and paper industry, similarly to fuelwood that commonly used in the food and beverage as well as ceramic industries (Vakkilainen et al., 2013). According Ogunsola et al. (2018), sawing waste and harvesting residue have been long used as raw material to produce electricity through biomass power plants. Another added material serving as the adhesive for wood pellet is tapioca flour. Adhesive application is intended to bind the wood particles or sawdust together and make them sturdy, also has the effect to improve the production process with a relatively low dust generated after the combustion (Amin, 2017). Diverse inputs eventually produce not only products but also emissions. Table 4 shows the calculated emission resulted from activities in the plantation and wood pellet mill.

Table 4 presents the wood production activities and calculated emission from each activity during one production cycle, per ha, for 100 ton of wood pellets in ITP. The largest emission or the greenhouse gas produced was emission in the form of $\mathrm{N}_{2} \mathrm{O}$ at the amount of $551.2927 \mathrm{~kg}$, followed by $\mathrm{NH}_{3}$ amounted at $7.5275 \mathrm{~kg}$. These two emissions were coming from the application of NPK fertilizer. Although $\mathrm{NH}_{3}$ is basic, the ammonium is then converted into nitrate, releasing $\mathrm{H}^{+}$and producing $\mathrm{NO} 3-\mathrm{N}$ in soil by bacteria, causing acidification of the soil. Meanwhile the eutrophication emissions in the form of $\mathrm{PO}_{4}^{3-}$ was very low, i.e., $0.1792-0.2229 \mathrm{~kg}$ from liquid fertilizers and pesticides. The main emitter of $\mathrm{N}_{2} \mathrm{O}$ is the addition of nitrogen to the soil, resulting nitrification and denitrification processes due to leaching and evaporation of the element (FAO, 2015). 
Table 3 Input energy and materials in industrial plantation and wood pellet mill

\begin{tabular}{|c|c|c|c|c|c|c|c|c|c|c|c|}
\hline Input per ha & SP & LP & $\mathrm{Pl}$ & $\mathrm{Hl}$ & $\mathrm{Hv}$ & $\mathrm{Tp}$ & WS & $\mathrm{CD}$ & $\mathrm{Pt}$ & St & Total \\
\hline \multicolumn{12}{|l|}{ Energy } \\
\hline Diesel (liter) & 132.50 & 3.50 & 28 & - & 162 & 120 & 162 & 110 & - & 70 & 788 \\
\hline Gasoline (liter) & 2.50 & 12.60 & - & - & 10 & - & - & - & - & - & 25.10 \\
\hline Electricity (kWh) & 131 & - & - & - & - & - & - & 700 & 477 & - & 1,308 \\
\hline \multicolumn{12}{|l|}{ Materials } \\
\hline Fertilizer N urea (kg) & 0.61 & - & - & 0.55 & - & - & - & - & - & - & 1.16 \\
\hline Fertilizer P SP $36(\mathrm{~kg})$ & - & - & 111.10 & - & - & - & - & - & - & - & 111.10 \\
\hline $\begin{array}{l}\text { Fertilizer NPK } \\
\text { compound } 65(\mathrm{~kg})\end{array}$ & 1.83 & - & - & 500 & - & - & - & - & - & - & 501.78 \\
\hline $\begin{array}{l}\text { Liquid fertilizer } \\
\text { growmore }(\mathrm{kg})\end{array}$ & 2 & - & - & - & - & - & - & - & - & - & 2 \\
\hline Pesticide (liter) & 6.20 & 4 & - & 4.66 & - & - & - & - & - & - & 14.86 \\
\hline Tapioca flour (kg) & - & - & - & - & - & - & - & - & 500 & - & 500 \\
\hline
\end{tabular}

Note: $\mathrm{SP}=$ seedling preparation; $\mathrm{LP}=$ land preparation; $\mathrm{Pl}=$ plantation; $\mathrm{Hl}=$ handling; $\mathrm{Hv}=$ harvesting; $\mathrm{Tp}=$ transportation; $\mathrm{WS}=$ wood shelters; $\mathrm{CD}=$ chipping and drying; $\mathrm{Pt}=$ pelleting; $\mathrm{St}=$ storage

Table 4 Output emissions GHG, acidification, and eutrophication of production wood pellet

\begin{tabular}{|c|c|c|c|c|c|c|c|}
\hline \multirow{2}{*}{ The process steps } & \multicolumn{7}{|c|}{ Emissions $\left(\mathrm{kg} \mathrm{ha}^{-1}\right)$} \\
\hline & $\mathrm{CO}_{2}$ & $\mathrm{CH}_{4}$ & $\mathrm{~N}_{2} \mathrm{O}$ & $\mathrm{SO}_{2}$ & NOx & $\mathrm{NH}_{3}$ & $\mathrm{PO}_{4}^{3-}$ \\
\hline \multicolumn{8}{|l|}{ Industrial plantation forest: } \\
\hline Diesel (liter) & 0.0918 & 0.0048 & 0.0037 & - & - & - & - \\
\hline Gasoline (liter) & 0.0057 & 0.0027 & 0.0003 & - & - & - & - \\
\hline Electricity (kWh) & 63.5350 & - & - & 1.0611 & 0.5463 & - & - \\
\hline Fertilizer N urea (kg) & - & - & - & - & 0.0027 & 0.0534 & - \\
\hline Fertilizer P SP 36 (kg) & - & - & 64.2036 & - & 0.2000 & 3.9996 & - \\
\hline Fertilizer NPK (kg) & - & - & 551.2927 & - & 0.3764 & 7.5275 & - \\
\hline Liquid fertilizer (kg) & - & - & - & - & 0.0070 & 0.1400 & 0.1792 \\
\hline Pesticide (liter) & - & - & - & - & - & - & 0.2229 \\
\hline \multicolumn{8}{|l|}{ Transportation: } \\
\hline Diesel (liter) & 0.0338 & 0.0018 & 0.0014 & - & - & - & - \\
\hline \multicolumn{8}{|l|}{ Wood pellet mill: } \\
\hline Diesel (liter) & 0.0963 & 0.0051 & 0.0039 & - & - & - & - \\
\hline Total & 63.76 & 0.01 & 614.36 & 1.06 & 0.59 & 11.72 & 0.40 \\
\hline
\end{tabular}

Furthermore, leaching of chemical materials from the using of fertilizer will have an impact on the surrounding groundwater quality and surface water or, more broadly, become the main pollutant of eutrophication (Divya \& Belagali., 2012; Astuti, 2019). As for the production process in the mill, the activity produces only $0.96 \mathrm{~kg}$ of $\mathrm{GHG}\left(\mathrm{CO}_{2}\right)$ that is resulted from diesel fuel combustion for transportation. According to Mfitumukiza et al. (2019), carbon dioxide emissions are produced mainly from the use of fossil fuels.

Potential impacts and environmental improvement of wood pellet production The stages in impact assessment of a life cycle translates information on material and energy flows that happen through-out the product's life cycle into environmentally relevant indicators, which is calculated as a whole into the impact category (Saade et al., 2019). GHG emissions of the production process are those resulted from chemical reactions or physically produced residual elements classified as $\mathrm{GHG}\left(\mathrm{CO}_{2}, \mathrm{CH}_{4}\right.$, and $\left.\mathrm{N}_{2} \mathrm{O}\right)$, causing global warming (Kweku et al., 2017). In addition, industrial activities also produce acidification emissions, such as $\mathrm{SO}_{2}$ and $\mathrm{NO}_{x}$, that cause acid rain (Handriyono \& Kusuma., 2017). Analysis of potential impact is carried out to identify in which stage of wood pellet production that contributes as the largest emitter, so that improvement can be made. The identified and calculated emissions are then classified by environmental impacts they cause, i.e. GHG emissions, acidification, and eutrophication (Table 5).

Table 5 shows that production of wood pellets at PT KTH emitted greenhouse gases of $678.0270 \mathrm{~kg} \mathrm{CO}_{2}$ eq, then the acidification of $13.3675 \mathrm{~kg} \mathrm{SO}$ eq, and eutrophication of $0.4021 \mathrm{~kg} \mathrm{PO}_{4}{ }^{3-} \mathrm{eq}$, which are generated starting from the stages of cultivation in the plantation area. The wood pellet mill only produced $0.1053 \mathrm{~kg} \mathrm{CO}$ eq of GHG emissions. This result is larger than a study by Pergola et al. (2017), 
Table 5 Potential impact of GHG, acidification, and eutrophication

\begin{tabular}{llccr}
\hline \multicolumn{1}{c}{ Impact category } & \multicolumn{1}{c}{ Unit } & Industrial timber plantation & Wood pellet mill & Total (kg) \\
\hline Greenhouse gases & $\mathrm{kg} \mathrm{CO}_{2} \mathrm{eq}$ & 678.0270 & 0.1053 & 678.1323 \\
Acidification & $\mathrm{kg} \mathrm{SO}_{2} \mathrm{eq}$ & 13.3675 & - & 13.3675 \\
Eutrophication & $\mathrm{kg} \mathrm{PO}_{4}^{3-} \mathrm{eq}$ & 0.4021 & - & 0.4021 \\
\hline
\end{tabular}

where production of 1 ton of wood pellets results in GHG emission, acidification, and eutrophication of $38 \mathrm{~kg} \mathrm{CO}_{2}$ eq, $1.4 \mathrm{~kg} \mathrm{SO}$ eq, $0.002 \mathrm{~kg} \mathrm{PO}_{4}^{3-}$ eq, respectively when using sawn timber waste of processing industry, and becoming 83 $\mathrm{kg} \mathrm{CO}_{2}$ eq, $2.7 \mathrm{~kg} \mathrm{SO}$ eq, and $0.005 \mathrm{~kg} \mathrm{PO}_{4}^{3-}$ eq, respectively when using timber directly obtained from the harvesting activities. The differences are due to the different scope of study, of which Pergola et al. (2017) scope is smaller, solely cover the harvesting and timber processing industry, and is managed to consider only fuel and electricity as the input.

The result of this research shows that wood pellet production has a considerable impact to the environment, i.e. by releasing some substances to the atmosphere and land. The substances are resulted from cultivation activity in ITP as the largest emissions, in the form of $\mathrm{GHG}$ and acidification, i.e. $\mathrm{CO}_{2}, \mathrm{CH}_{4}, \mathrm{~N}_{2} \mathrm{O}, \mathrm{SO}_{2}$ and $\mathrm{NO}_{x}$. According Abeydeera et al. (2019), excessive $\mathrm{CO}_{2}$ emissions will increase atmospheric GHGs which have an impact on global warming. Acidification causes the loss of base cations, could increase aluminum saturation and a decline in crop yields; severe acidification can cause nonreversible clay mineral dissolution and a reduction in cation exchange capacity, accompanied by structural deterioration (Goulding, 2016). Eutrophication pollution will cause an increased density of phytoplankton, resulting in dissolved oxygen depletion and the emergence of toxic gases, such as ammonia and hydrogen sulfide that can harm aquatic fauna including fish (Khan \& Mohammad., 2013). However, the plantation area of PT KTH is also able to absorb the $\mathrm{CO}_{2}$ in the atmosphere into its forest biomass and balance its GHG emissions, also reducing the GHG production's adverse impacts on the environment (Figure 3).

Figure 3 shows that 4-year-old E. pellita stands are able to absorb $\mathrm{CO}_{2}$ at 67.69 ton ha $^{-1}$ year ${ }^{-1}$, which is higher compared to emissions released by wood pellet production at only 0.68 ton year ${ }^{-1}$ which was significantly lower. According to Hardiansyah, (2012), the potential of E. pellita stands aged at $1,2,4$, and 5 years can absorb $\mathrm{CO}_{2}$ gas from the atmosphere ranging from 3,783-675,639 ton $\mathrm{ha}^{-1} \mathrm{CO}_{2}$, of which the absorbed gas is then distributed into stored plant organs as biomass. The existence of green open space in the industrial complex can be used as an effort to reduce $\mathrm{CO}_{2}$ and other emissions, and to maximize this capability through planting vegetation that has a large $\mathrm{CO}_{2}$ absorption capacity. This indicates that industrial plantation forests are still able to absorb much higher GHG or $\mathrm{CO}_{2}$ released into the air from wood pellet production. Therefore, the main priority of environmental improvement that can be done is to minimize the contributors to the emission, by identification of dieselfueled electricity and change it into biodiesel, also change the fossil fuel based electricity from national power plants to biomass based or solar-based power plants, so that emissions can be reduced or minimize negative impacts on environment.

\section{Conclusion}

Considering most forestry activity in Indonesia is carbon source rather than sink, the LCA analysis shows that ITP that produce wood pellet is found out as net-zero emission business. The first largest input energy on the wood pellet production was electricity of $1,308 \mathrm{kWh}$, which is used in wood pellet factories in the chipping and pelleting process. The second largest input was $788 \mathrm{~L}$ of diesel fuel, for running the plantation and wood pellet factory. As for materials, the most widely used input was $500 \mathrm{~kg}$ of NPK Fertilizer for seedlings preparation and plants maintenance, followed by $\mathrm{P}$ fertilizer of $111.10 \mathrm{~kg}$, used in the transplanting. The output of the whole system produced the largest emission, which was the GHG emission in the form of $\mathrm{N}_{2} \mathrm{O}$ of $551.2927 \mathrm{~kg}$, then the acidification emission in the form of $\mathrm{NH}_{3} 7.5275 \mathrm{~kg}$, of which both emissions are generated from NPK fertilizer. As for the eutrophication emissions in the form of $\mathrm{PO}_{4}^{3-}$ are very low even close to zero, namely $0.1792-0.2229 \mathrm{~kg}$, which came from liquid fertilizers and pesticides. On the other hand, the wood pellet mill only released $0.1053 \mathrm{~kg} \mathrm{CO}_{2}$ eq of GHG emissions. Total potential GHG emissions, acidification, and eutrophication resulting from the whole production lines of wood pellets starting from plantation, were GHG emissions of $678.0270 \mathrm{~kg} \mathrm{CO}_{2} \mathrm{eq}$, then the acidification of $13.3675 \mathrm{~kg} \mathrm{SO}_{2}$ eq and eutrophication 0.4021 $\mathrm{kg} \mathrm{PO}_{4}^{3-}$ eq, respectively. Yet, those total emissions released from the production of wood pellets are still quite low compared to annual plantation's capacity to absorb $\mathrm{CO}_{2}$ gas in the atmosphere which is very high at 41.18-67.69 ton ha ${ }^{-1}$ year $^{-1}$ on the average.

\section{References}

Abeydeera, L. H. U. W., Mesthrige, J. W., \& Samarasinghalage, T. J. (2019). Global research on carbon emissions: a scientometric review. Sustainbility, 11,(39-72), 124. https://doi.org/10.3390/su11143972

Agostini, A., Giuntoli, J., Mareli, L., \& Amaducci, S. (2019). Flaws in the interpretation phase of bioenergy LCA the fuel debate and mislead policymakers. The International Journal of Life Cycle Assessment, 1-19. https://doi.org/ 10.1007/s11367-019-01654-2

Aisya, N. S. (2019). Dilema posisi Indonesia dalam persetujuan Paris tentang perubahan iklim. Indonesia Perspective, 4(2), 118-132.

Amin, A. Z., Pramono., \& Sunyoto. (2017). Pengaruh variasi jumlah perekat tepung tapioka terhadap karakteristik 
briket arang tempurung kelapa. Sainteknol: Jurnal Sains dan Teknologi, 5(2), 111-118. https://doi.org/10.15294/ sainteknol.v15i2.11693

Astuti, A. D., (2019). Analisis potensi dampak lingkungan dari budidaya tebu menggunakan pendekatan Life Cycle Assessment (LCA). Jurnal Litbang: Media Informasi Penelitian, Pengembangan dan IPTEK, 15(1), 51-64. https://doi.org/10.33658/jl.v15i1.127

Aziz, I. (2008). Pembuatan biodiesel dari minyak goreng bekas dalam reaktor tangki alir berpengaduk. Jurnal Kimia Valensi, 1(2), 100-103. https://doi.org/10.15408/ jkv.v1i2.257

Baubus, J., Meer, P. V. D., \& Kannine, M. (2010). Ecosystem goods and services from plantation forest. Washington: Earthscan.

Carle, J., Vuorinen, P., \& Lungo, A. D. (2002). Status and trend in global forest plantation development. Journal Forest Products, 52(7), 1-13.

Daddi, T., Nucci, B., \& Iraldo, F. (2017). Using life cycle assessment (LCA) to measure the environmental benefits of industrial symbiosis in an industrial cluster of SMEs. Journal of Cleaner Production, 147, 157-164. https://doi.org/10.1016/j.jclepro.2017.01.090

Damalas, C. A., \& Eleftherohorinos, I. G., (2011). Pesticide exposure, safety issues, and risk assessment indicators. International Journal of Enviromental Research and Public Health, 8(5), 1402-1419. https://doi.org/ 10.3390/ijerph8051402

Divya, J., \& Belagali, S. L. (2012). Impact of chemical fertilizers on water quality in selected agricultural areas of Mysore District, Karnataka, India. International Journal of Environmental Sciences, 2(3), 1449-1458. https://doi.org/10.6088/ijes.00202030030

[EEA] European Environment Agency. (2006). Emission inventory guidebook. Luxembourg: The European Union.

[FAO] Food and Agriculture Organization. (2015). Global database of GHG emissions related to feed crops. Food and Agriculture Organization of The United Nations and Livestock Enviromental Assessment and Performance Partnership; Draft Version for Review. Roma: FAO.

Goulding, K. W. (2016). Soil acidification and the importance of liming agricultural soils with particular reference to the United Kingdom. Soil Use Management, 32(3), 390-399. https://doi.org/10.1111/sum.12270.

Handriyono, R. E., \& Kusuma, M. N. (2017). Estimates for $\mathrm{SO}_{2}$ and $\mathrm{NOx}$ emissions from industrial activities in Karang Pilang Surabaya (pp. 19-24). Seminar Nasional Sains dan Teknologi Terapan V 2017. Surabaya: Institut Teknologi Adhi Tama Surabaya.
Hardiansyah, G. (2012). The potential studi of biomass and carbon of Eucalyptus pellita from industrial forest plantation of PT. Finnantara Intiga in West Kalimantan. Jurnal Wana Tropika, 2(2), 72-81.

Herawan, T., \& Leksono, B. (2018). Regenerasi in vitro Eucalyptus pellita F. Muell menggunakan kultur mata tunas. Jurnal Perbenihan Tanaman Hutan, 6(1), 1-13. https://doi.org/10.20886/bptpth.2018.6.1.1-13

[IPCC] Intergovernmental Panel on Climate Change. (2006). IPPC guidelines for national greenhouse gas inventories $-A$ primer, Prepared by the National Greenhouse Gas Inventories Programme, H. S. Eggleston, K. Miwa, N. Srivastava, \& K. Tanabe (Eds.). Kagawa: The Institute for Global Environmental Strategies (IGES).

Kaygusuz, K., Toksoy, D., \& Bayramoglu, M. M. (2017). Global utilization of wood pellet for residential heating. Journal of Engineering Research and Applied Science, 6(2), 688-697.

Khan, M. N, \& Mohammad, F. (2013). Eutrophication: Challenges and solustions. In A. Ansari, \& S. Gill (Eds.), Eutrophication: Causes, consequences and control (pp. 1-15) Springer, Dordrech. https://doi.org/10.1007/97894-007-7814-6 1

Kuzgunkaya, E. H. (2015). Evaluation of Turkey's geothermal energy resources in terms of energy analysis. Proceedings world geothermal congress. Melbourne. Retrived from https://pdfs.semanticscholar.org/c818/ ebf8dabefa57c44e6b65422f9ea54fe1a7a8.pdf

Kweku, D. K., Bismark, O., Maxwel, A., Desmond, K. A., Danso, K. B., Mensah, E. A. O., ..., \& Adormaa, B. B. (2017). Greenhouse effect: Greenhouse gases and their impact on global warming. Journal of Scientific Research and Reports, 17(6), 1-9. https://doi.org/10.9734/JSRR/ 2017/39630

Lukmandaru, G., Zumaini, U. F., Soeprijadi, D., Nugroho, W. D., \& Susanto, M. (2016). Chemical properties and fiber dimension of Eucalyptus pellita from the 2nd generation of progeny test in Pelaihari, South Borneo, Indonesia. Journal of Korean Wood Science Technology, 44(4), 571-588. https://doi.org/10.5658/WOOD.2016.44.4.571

McKendry, P. (2002). Energy production from biomass (part 1): Overview of biomass. Bioresource Technology, 83, 37-46. https://doi.org/10.1016/S0960-8524(01)00118-3

Mfitumukiza, D., Nambasa, H., \& Walakira, P. (2019). Life cycle assessment of products from agro-based companies in Uganda. The International Journal of Life Cycle Assessment, 24, 1925-1936. https://doi.org/10.1007/ s11367-019-01629-3

Moreno, M. A. P., Manzano, E. S., \& Moreno, A. J. P. (2019). Biomass as renewable energy: worldwide research trends. 
Journal Sustainability, 11, 1-9. https://doi.org/ 10.3390/su11030863

Ogunsola, O. E., Adeleke, O., \& Aruna, A. T. (2018). Wood fuel analysis of some selected wood species within Ibadan. IOP Conference Series: Earth and Environmental Science, 173, 012043 https://doi.org/ $10.1088 / 1755-1315 / 173 / 1 / 012043$

Pergola, M., Gialdini, A., Celano, G., Basile, M., Caniani, D., Cozzi, M., \& Ripulone, F. (2017). An enviromental and economic analysis of the wood-pellet chain: two case studies in Southern Italy. The International Journal of Life Cycle Assessment, 23, 1675-1684. https://doi.org/ 10.1007/s11367-017-1374-z

Purba, R. (2014). Applications of NPK phonska and KCI fertilizer for the growth and yield of shallot (Allium ascalonicum) in Serang, Banten. International Journal of Applied and Technology, 4(3), 197-203.

Saade, M. R. M., Passer, A., \& Mittermayr, F. (2019). (Sprayed) concrete production in life cycle assessment: A systematic literature review. The International Journal of Life Cycle Assessment, 24, 1-20. https://doi.org/10.1007/ s11367-019-01676-w

Shinya, Y., \& Yukihiko, M. (2008). Buku panduan biomassa
Asia: Panduan untuk produksi dan pemanfaatan biomassa. Japan: The Japan Institute of Energy.

Singh, V., \& Toky, O. P. (1995). Biomass and net primary productivity in Leucaena, Acacia, and Eucalyptus, short rotation, high density (energy) plantations in arid India. Journal of Arid Environments, 31, 301-309. https://doi.org/10.1016/S0140-1963(05)80034-5

Susanto, J. P., Santoso, A. D., \& Suwedi, N. (2017). Perhitungan potensi limbah padat kelapa sawit untuk sumber energi terbarukan dengan metode LCA. Jurnal Teknologi Lingkungan, 18(2), 165-172. https://doi.org/ 10.29122/jtl.v18i2.2046

[UNFCCC] The United Nations Framework Convention on Climate Change. (2006). Greenhouse gas inventory submission. In B. Daniel, N. M. Ohlendorf (Eds.). Bonn: Intergovernmental and Legal Affairs Climate Change Secretariat.

[UNFCCC] The United Nations Framework Convention on Climate Change. (2015). Adoption of the Paris Agreement. Paris: United Nations.

Vakkilainen, E., Kuparinen, K., \& Heinimo, J. (2013). Large industrial users of energy biomass. Lappeenranta University of Technology. Finland: IEA Bioenergy. 